\title{
REVITALISASI EKONOMI UNTUK MENINGKATKAN PRODUKTIVITAS, NILAI TAMBAH DAN AKSES PASAR BERBASIS KELESTARIAN KAWASAN HUTAN LINDUNG “BUKIT DAUN” DI KABUPATEN REJANG LEBONG
}

\author{
Soengkono \\ Anggri Puspita Sari \\ Fakultas Ekonomi dan Bisnis Universitas Bengkulu
}

\begin{abstract}
ABSTRAK
Soengkono, Anggri Puspita Sari; Penelitian ini berangkat dari kegagalan Pengembangan Hutan Masyarakat (Hak.) yang sampai sekarang belum pernah mampu membuka sepenuhnya dan masih menyimpan masalah berlama-lama. Berdasarkan fenomena tersebut, penelitian ini bertujuan untuk merevitalisasi potensi ekonomi ekonomi lokal berbasis sumber daya dan kelestarian hutan lindung melalui inovasi teknologi terintegrasi yang tepat untuk meningkatkan produktivitas, nilai tambah dan akses pasar yang berkelanjutan. Penelitian ini dirancang untuk diselesaikan selama 2 (dua) tahun dengan menggabungkan dua pendekatan, yaitu, pembangunan ekonomi dan keberlanjutan ekonomi subsistem sub-sistem agribisnis hulu hilir untuk melindungi dan melestarikan keutuhan ekosistem hutan lindung. Untuk mencapai tujuan penelitian ini adalah dengan menggunakan pendekatan PRA (Participatory Rural Appraisal), kualitatif, dan tindakan (action research). Informasi yang diperoleh melalui mendalam teknik wawancara (indept interview), observasi, diskusi kelompok terfokus (Focus Group Discussion) dan curah pendapat (Brainstorming) di media klasik. Analisis data dilakukan bersamaan dengan proses pengumpulan data (analisis akan) dan teknik teknik yang berlaku dalam penelitihan kualitatif. Pengembangan teknologi tepat guna Model yang digunakan disesuaikan, diatur dengan potensi sumber daya manusia yang ada, sumber daya alam, keberadaan potensi tim ahli, serta potensi lingkungan bisnis yang ada. Model pengembangan diarahkan pada pembentukan kelompok masyarakat petani kopi produktif, pengembangan yang sesuai produksi modul teknologi pengolahan kopi dan bisnis percetakan kemasan. Kelompok masyarakat diarahkan untuk produksi pendirian usaha pengolahan kopi dan kemasan bisnis percetakan melalui kegiatan pelatihan terstruktur, pembentukan unit bisnis, manajemen bisnis, pembinaan dan upaya pengembangan pembinaan. Tim peneliti memberikan konsultasi teknologi bantuan, sertifikasi produk, serta pemasaran pengembangan pembinaan. Pada kegiatan ini juga akan dikembangkan untuk mendukung peran mitra bisnis dalam pengembangan usaha, termasuk dukungan dari Pemerintah, pengusaha, dan sumber modal.
\end{abstract}

\section{ABSTRACT}

Soengkono, Anggri Puspita Sari; This study departs from the failure of the Development Community Forests (Judg.) which until now had never been able to open completely and still keep problems lingering. Based on such phenomena, research aims to revitalize the economic potential of the resource-based local economy and protected forest sustainability through appropriate integrated technological innovation to increase productivity, added value and sustainable market access. This research is designed to be completed during the 2 (two) years by combining two approaches, namely, the economic development and economic sustainability of downstream subsystem sub-system upstream agribusiness to protect and preserve the integrity of protected forest ecosystems. To achieve the goal of this research is to use PRA approach (Participatory Rural Appraisal), qualitative, and action (action research). Information obtained through in-depth interview techniques (indept interview), observations, focused group discussions (Focus Group Discussion) and brainstorming (brainstorming) in the classical media. Data analysis was carried out simultaneously with the process of data collection (on going analysis) and the applicable techniques techniques in qualitative penelitihan. Appropriate technology development Model used adapted, arranged with the potential of existing human resources, natural resources, the potential 
existence of a team of experts, as well as the potential of the existing business environment. Model development is directed to the formation of groups of people of productive coffee farmers, the development of appropriate technology module production of coffee processing and packaging printing business. Community groups geared to business establishment production of coffee processing and packaging printing business through structured training activities, the establishment of business units, business management, coaching and coaching development effort. The research team gave assistance technology consulting, product certification, as well as coaching development marketing. On these activities will also be developed to support business partner role in enterprise development, including support of the Government, employers, and sources of capital.

\section{Key words: Revitalization, Economic, Technology, Productivity, Sustainability}

\section{PENDAHULUAN}

Fenomena yang terjadi pada tataran empirik bahwa permasalahan intervensi atau tekanan manusia dalam pemanfaatan kawasan hutan lindung tidak pernah mampu terselesaikan dengan tuntas. Konservasi dan pelestarian hutan lindung sampai sekarang masih menyimpan banyak masalah, terutama berkaitan ketergantungan masyarakat petani untuk kegiatan ekonomi (baca: berkebun kopi) di kawasan hutan lindung (Soengkono; 2006; 2007; 2009). Sementara itu, paradigma pembangunan kehutanan yang selama ini dilakukan seperti penerapan Program Perhutanan Sosial (Social Forestry) yakni Pola Pembangunan Hutan Kemasyarakatan $(\mathrm{HKm})$ cenderung mengedepankan kepentingan pemerintah sebagai pelaku utama dalam pembangunan kehutanan dan bukan kepentingan multy stakeholders, yakni: pemerintah, masyarakat dan pihak-pihak terkait lainnya. Kondisi ini diperjelas dari hasil penelitian Soengkono (2007) mengungkap bahwa Program Pembangunan Hutan Kemasyarakatan di Desa Air Lanang Kabupaten Rejang Lebong, Desa Ujan Mas Atas, dan Desa Tanjung Alam di Kabupaten Kepahiang mengalami kegagalan dan bahkan menyimpan banyak permasalahan yang sampai saat ini permasalahan tersebut tidak pernah ada penyalesaian secara tuntas. Kegagalan program HKm. lebih diakibatkan pada: (1) awal proses sosialisasi program dalam tahap mempersiapkan masyarakat untuk menerima program HKm tidak melalui proses transaksional dialogis antara pelaksana kegiatan dan masyarakat sebagai sasaran program, sehingga program terkesan dipaksakan dan bahkan image masyarakat yang berkembang adalah program HKm adalah program yang memisahkan masyarakat dengan hutan yang merupakan suatu sistem pendukung kehidupan mereka (life-support system); (2) Pelaksanaan program tidak terstruktur dan tidak terukur, sehingga tahapan-tahapan dalam pelaksanaan terkesan asal jalan, akibatnya masyarakat kesulitan dalam mengikuti pelaksanaan program; (3) Pelaksanaan program tidak mengembangkan pola pengelolaan hutan dengan model integrated community-based forest management, seperti yang tertuang dalam kebijakan $\mathrm{HKm}$.

Berdasarkan fenomena-fenomena yang terjadi di tataran empirik tersebut, peneltian ini bertujuan revitalisasi ekonomi produktif berbasis kelestarian hutan lindung melalui inovasi teknologi tepat guna terpadu untuk meningkatkan produktivitas, nilai tambah dan akses pasar berbasis potensi sumberdaya ekonomi lokal yang berkelanjutan.Penelitian ini dirancang dapat diselesaikan selama 2 (dua) tahun dengan memadukan 2 (dua) pendekatan, yakni pengembangan ekonomi sub-sistem agribisnis hilir untuk usaha mikro produktif dan pengembangan ekonomi sub-sistem agribisnis hulu untuk melindungi dan menjaga integritas ekosistem hutan lindung.Upaya-upaya revitalisasi ekonomi masyarakat berbasis potensi lokal dan kelestarian hutan perlu terus digali, dikaji, ditemukenali dan selanjutnya diimplementasikan dalam kerangka meningkatkan pendapatan masyarakat petani di desa penyangga kawasan hutan lindung. Hal ini dimaksudkan dengan adanya kegiatan ekonomi di desa, intensitas perambahan dalam memperluas area peladangan (baca: perambahan) dan penebangan liar dapat dikurangi. Selain itu kegiatan reboisasi (baca: pengkayaan HKm) yang sifatnya memiliki nilai ekonomi perlu terus diupayakan dan dikembangkan agar tingkat pendapatan dan pelestarian hutan lindung tetap terjaga sebagai suatu alternatif model sistem 
pengelolaan dan pengusahaan hutan berbasis masyarakat (community-bassed forest management).

Dari hasil penelitian Soengkono, (2007) terdapat adanya permasalahan yang perlu secepatnya mendapatkan penyelesaian dalam upaya mengurangi tekanan ekonomi keluarga petani kopi sebagai akibat kegagalan program Hutan Kemasyarakatan (HKm).

Rumusan permasalahan tersebut adalah:

1. Komoditas unggulan program HKm. yakni tanaman kemiri yang direncanakan mampu meningkatkan pendapatan petani kopi sampai pada tahun 2007 (baca: tahun ketujuh) tidak berbuah atau tidak menghasilkan. Kondisi tekanan ekonomi ini, bila dibiarkan akan mendorong masyarakat petani kopi untuk kembali melakukan perambahan di kawasan hutan lindung Bukit Daun.

2. Ketergantungan kehidupan ekonomi masyarakat petani kopi dengan kawasan hutan lindung "Bukit Daun" sangat tinggi (life-support system).

3. Tanaman turun-menurun, yakni tanaman kopi (haus lahan) masih merupakan matapencaharian pokok dan sebanyak 70\% masih berada di kawasan Hutan Lindung Bukit Daun (baca: potensi merambah tinggi).

4. Pemasaran hasil pasca panen terutama oleh petani kopi tradisional masih konvensional, yakni petik langsung jual dalam bentuk biji basah dengan harga murah. Sebenarnya dengan sentuhan teknologi sederhana, komoditas tersebut masih memiliki nilai ekonomi tinggi (added value). Kondisi ini membuat masyarakat tidak mampu dan mengalami kesulitan untuk memenuhi kebutuhan ekonomi minimal keluarga.

5. Berkaitan dengan no.4 dan desakan kebutuhan ekonomi rumahtangganya, menyebabkan tumbuh dan berkembangnya pola "Sistem Ijon"

6. Keterbatasan input teknologi tepatguna dalam pengelolaan pasca panen kopi.

7. Tidak adanya pembinaan usaha-usaha ekonomi produktif alternatif berdimensi konservasi dan pelestarian alam pasca palaksanaan Program Pembangunan HKm.

\section{Landasan Teori}

Konflik masyarakat terhadap lingkungan (hutan) tergambarkan dalam permasalahan sosial yang belum terselesaikan hingga saat ini.Terlebih lagi dengan adanya persepsi bahwa masyarakat yang berdomisili di sekitar hutan menjadi sumber utama yang menyebabkan terjadinya kerusakan hutan pada setiap tahun.Kenyataannya, justru maraknya pengusahaan hutan justru yang mempercepat terjadinya degradasi hutan dan lahan tersebut.Kebijakan dengan menutup akses masyarakat setempat terhadap kawasan hutan pada dasarnya sangat tidak tepat karena dapat menghambat kelangsungan penghidupan mereka yang sangat menggantungkan hidup dari mengelola dan memanfaatkan hutan (Kusworo, 2001).

Pemanfaatan hutan secara komersial sebagai penggerak perekonomian nasional telah dimulai sejak tahun 1967 dalam bentuk ekspor kayu tropis dunia yang diawali dengan ekspor log, kayu gergajian, kayu lapis, dan produk kayu olahan lainnya. Namun, memasuki tahun 1995an mulai terlihat adanya ketidakseimbangan antara laju eksploitasi dengan kemampuan untuk merehabilitasinya (Arifin, et.all, 2004). Hal ini juga menjadi salah satu penyebab terjadinya permasalahan social dan ekonomi dalam lingkungan masyarakat di sekitar hutan.

Adanya berbagai fenomena konflik dalam lingkungan sosial ekonomi masyarakat tersebut membuat pandangan kita menjadi terbuka bahwa semua masalah sosial dan ekonomi yang ada tersebut selalu berasal dari masalah kependudukan (Simon, 1993). Sebagai suatu sistem, tidak dapat dihindari bahwa kehutanan akan selalu berhadapan dengan seperangkat masalah yang berkaitan dengan manusia. Rasio lahan per orang akan menjadi berkurang dengan terus meningkatnya pertambahan penduduk, termasuk lahan garapan dan lahan pertanian, sehingga mendorong terjadinya perluasan areal permukiman sampai ke daerahdaerah yang berbatasan langsung dengan kawasan hutan. Realita inilah yang menyebabkan kian eratnya hubungan masyarakat dengan kawasan hutan.

Masyarakat sekitar kawasan hutan sesungguhnya memiliki kearifan lokal sebagai embrio yang dapat menyelamatkan sumberdaya alam, khususnya sumberdaya hutan. Kearifan ini juga dapat digunakan untuk menghentikan penyimpangan dalam pengelolaan sumberdaya 
hutan ke depan sehingga dapat menjadi tumpuan penggerak utama roda perekonomian nasional (Anonim, 2004). Namun demikian, karena berbagai tuntutan ekonomi, maka pelaksanannya bervariasi dan mengalami pasang surut dari waktu ke waktu, dari tempat ke tempat dan dari petani ke petani.

Sarwono (1993) dalam Ratnanda dan Yusuf (2002) menyebutkan bahwa perilaku seseorang merupakan hasil dari segala macam pengalaman serta interaksi seseorang dengan lingkungan yang terwujud dalam bentuk pengetahuan, sikap, dan tindakan yang merupakan respond atau reaksi seseorang individu terhadap rangsangan yang berasal dari luar maupun dari dalam dirinya. Kesediaan masyarakat untuk melakukan kegiatan konservasi hutan dapat dikategorikan sebagai suatu perilaku.

Sementara itu Sahlins (dalam Soengkono, 2007) mendefinisikan perilaku manusia dalam hubungannya dengan lingkungannya adalah sebagai proses yang menunjukkan tingkatan aksi pada individu yang ditunjukkan pada upaya memaksimalkan kesempatan hidup, termasuk memaksimalkan lingkungan fisik dan lingkungan sosial. Dengan demikian Sahlins menekankan bahwa interaksi pada lingkungan diarahkan untuk memuaskan tujuan manusia.Selain itu, Sahlins menyatakan bahwa perilaku manusia terus berubah dari waktu ke waktu. Perubahan perilaku dari sudut pandang ekologi sosial ekonomi dan budaya, adalah suatu tindakan atau kepribadian individu (individual personality) yang mengasumsikan bahwa (1) pengaruh utama terhadap perilaku manusia datang dari lingkungan dan karena itu (2) yang menjadi pusat perhatian utama seharusnya adalah perbedaan situasi dan kondisi, dimana manusia bertempat tinggal, bukan perbedaan individu (Valentyne dan Hamilton dalam Soengkono, 2007).

Pembangunan kehutanan berbasis masyarakat (community-bassed forest development) yang berorientasi forest for people seringkali dihadapkan pada permasalahan yang tidak pernah dapat diselesaikan dengan tuntas.Tekanan pertumbuhan penduduk dan intensitas aktivitas ekonomi di wilayah enclave atau kawasan penyangga hutan konversi dari waktu ke waktu cenderung meningkat yang ditunjukkan oleh aktivitas perambahan, perburuan satwa dan berbagai kasus pembalakan liar serta pencurian hasil hutan lainnya, terutama yang mempunyai nilai ekonomi tinggi (Suminar, 1999; Soengkono, 2004 dan 2007; Praningrum, 2007).Tekanan penduduk pada kawasan hutan lindung ini ditunjukkan oleh hasil penelitian Soengkono, (2007) yang menjelaskan bahwa masyarakat beranggapan bahwa hutan adalah kehidupan bagi keluarga mereka.Hutan bagi mereka merupakan wilayah yang mampu menyangga kehidupan ekonomi keluarga.Dari generasi ke generasi berikutnya, interaksi masyarakat terhadap hutan ditunjukkan oleh pemanfaatan kawasan hutan untuk menjamin kelangsungan hidup dalam memenuhi kebutuhan ekonomi keluarga mereka.Oleh karenanya pola yang dikembangkan masyarakat lebih kepada upaya pemanfaatan hutan semaksimal mungkin dan seringkali mengesampingkan aspek pelestariannya.Cara pandang demikian pada gilirannya menyebabkan tingkat intervensi manusia terhadap hutan telah melewati batas-batas kemampuan ekologi hutan dalam menyediakan kebutuhan kehidupan manusia. Akibatnya, ekosistem hutan akan terganggu dan kehilangan keanekaragan hayati yang terkandung di dalamnya. Selain itu masyarakat penyangga kawasan hutan lindung menurut hasil penelitian Praningrum (2007) menunjukkan bahwa masyarakat dalam aktivitas ekonominya dan lebih kurang $85 \%$ kebunnya berada di hutan lindung. Masyarakat tetap melakukan perambahan dalam memperluas area perkebunan kopinya.Namun secara umum kondisi masyarakatnya masih tetap saja miskin.

Paradigma lama pembangunan kehutanan cenderung mengedepankan kepentingan pemerintah sebagai pelaku utama dalam pembangunan kehutanan. Seharusnya bagi pengambil kebijakan dibidang pembangunan kehutanan, baik pusat maupun daerah lebih mengembangkan pola pengelolaan hutan dengan model integrated community-bassed forest management. Hal ini ditunjukkan oleh hasil penelitian Soengkono (2007) yang mengatakan bahwa transaksi dialogis dalam menemukenali model dalam membuat program pembangunan kehutanan berbasis kepentingan stake holders baca: masyarakat sasaran dan pemangku program) adalah sangat penting. Model tersebut dapat dijadikan media untuk memadukan dua kepentingan yang berbeda dengan cara memformulasikan kesamaan hak dan kewajiban masing-masing pihak, yakni antara pemerintah dan komunitas Penyangga hutan lindung. Bagi pemerintah atau instansi terkait harus memandang bahwa komunitas Penyanga hutan harus dipandang sebagai 
bagian dari sebuah ekosistem hutan. Setiap kebijakan yang mencabut masyarakat dari ekosistemnya akan menimbulkan resistensi komunitas yang bersangkutan.

Dalam paradigma baru, setiap kebijakan yang akan dibuat terlebih dahulu harus melalui proses transaksional dialogis antara antara stakeholders yang selama ini berkepentingan dengan keberadaan hutan lindung.Paradigma baru ini sebenarnya telah digulirkan oleh pemerintah dalam implementasi Program Pembangunan Hutan Kemasyarakatan (HKm).Paradigma baru ini mempunyai substansi bahwa pembangunan kehutanan merupakan tugas kita bersama, dimana peran masyarakat menjadi lebih penting.Paradigma baru ini pada dasarnya merupakan bentuk manajemen yang berbasis pada masyarakat (Community-Based Forest Management).Melalui penggunaan pendekatan partisipatif dengan tujuan meningkatkan kesejahteraan masyarakat tanpa mengurangi fungsi ekologis dari sumberdaya alam (Departemen Kehutanan dan Perkebunan, 1998). Pendekatan ini sangat tepat dalam menjembatani kepetingan pemerintah dengan kepentingan masyarakat Penyangga kawasan hutan lindung, walaupun kadangkala di lapangan seringkali ada perbedaan antara apa yang direncanakan dengan pelaksanaannya. Dalam kenyataannya, hasil penelitian evaluatif yang dilakukan oleh Soengkono (2007) membuktikan bahwa pelaksanaan program pembangunan hutan kemasyarakatan dinilai gagal, hal ini disebabkan tanaman pokok hutan kemasyarakatan (multi purpose tries/MPTs) (baca=kemiri) sampai dengan tahun yang dijanjikan tidak berbuah. Kejadian ini membuat masyarakat anggota $\mathrm{HKm}$ melakukan inisiatif akan kembali ke tanaman kopi dan melakukan penebangan tanaman kemiri Sulawesi yang tidak menghasilkan tersebut.

Berdasarkan pada kondisi tersebut, ke depan sangat diperlukan adanya pola pendekatan persuasif melalui rivitalisasi ekonomi masyarakat dengan menggunakan berbagai kombinasi strategis melalui penerapan teknologi tepatguna terpadu berbasis pada potensi ekonomi lokal. Penguatan peran ekonomi masyarakat yang berdimensi pada proses penyadaran (awareness) psikologi masyarakat sebenarnya akan menjadi lebih penting dalam menjaga kelestarian hutan sebagai satu sistem pendukung kehidupan (life-support system). Strategi pemberdayaan ekonomi masyarakat berbasis pada konservasi dan pelestarian sebagai media pendidikan lingkungan pada masyarakat sebaiknya dilakukan melalui pemanfaatan potensi ekonomi local, yakni: potensi sumberdaya alam dan potensi sumberdaya manusia, agar dalam proses diseminasi dapat dengan mudah diadopsi oleh masyarakat sasaran penelitian.

\section{METODE PENELITIAN}

Pendekatan kualitatif, yaitu langsung mengarahkan pada keadaan dan pelaku-pelaku tanpa mengurangi unsur-unsur yang ada di dalamnya.Dengan pendekatan ini dapat dipahami kehidupan masyarakat petani kopi, khususnya yang berkaitan dengan pemberdayaan peran ekonomi masyarakat petani yang berbasis pada kearifan lokal (ESDM dan ESDA) secara dekat, dan dapat pula memahami faktor-faktor yang melatarbelakanginya. Keuntungan dengan menggunakan pendekatan ini, antara lain: peneliti akan dapat lebih mendalam, sehingga dapat menjawab mengapa hal itu terjadi dan bagaimana menemukan penyelesaiannya bersama objek penelitian. Makna dan konsep yang digunakan dalam kajian ini dapat pula tertangkap dengan menggunakan metode studi kasus dan ekplorasi yang bertujuan untuk mengembangkan pengetahuan yang mendalam mengenai obyek yang bersangkutan (Bogdan dan Taylor, 1995).

Sumber data penelitian ini terdiri dari data sekunder dan data primer.Data sekunder diperoleh dari instansi atau lembaga, baik formal maupun informal yang menyediakan informasi relevan dengan tujuan dan maksud penelitian.Sedangkan data primer terutama bersumber dari lapangan penelitian yang diperoleh melalui pengamatan dan curah pendapat.Di samping teknik-teknik pengumpulan data tersebut, maka dalam penelitian ini juga digunakan pendekatan Participatory Rural Appraisal atau PRA (Chambers, 1992), melalui FGD, indepth interview, observasi partisipatori, kalender musin, dan timelines.

\section{HASIL PENELITIAN}

\section{Desain Revitalisasi Ekonomi Untuk Meningkatkan Produktivitas, Nilai Tambah Dan Akses Pasar Berbasis Kelestarian Kawasan Hutan Lindung}




\section{a. Sosialisasi Program}

Suatu kegiatan tepat mencapai tujuan yang telah ditetapkan sebelumnya jika dilakukan dengan perencanaan yang matang dan melalui tahapan-tahapan yang sistematis. Samal halnya dengan kegiatan penelitian ini. Untuk mencapai tujuan, maka di awal-awal kegiatan dilakukan proses identifikasi dan sosialisasi kegiatan. Tujuannya adalah agar terjadi kesatuan visi dan misi antara peneliti dan masyarakat sasaran, sehingga pada saat pelaksanaan tindakan tidak menemui kendala. Pada kegiatan ini tim peneliti melakukan kegiatan pertemuan dengan masyarakat kelompok tani HKm sebagai sasaran kegiatan, tokoh masyarakat, aparat desa formal dan non formal untuk mensosialisasikan kedatangan tim peneliti sekaligus perkenalan dan pengakraban.

\section{b. Identifikasi, Pemecahan Masalah dan Need Assesment}

Dalam tahap ini kegiatan yang dilakukan adalah :

1. Identifikasi permasalah $\mathrm{HKm}$, konservasi lahan dan upaya peningkatan ekonomi masyarakat petani peserta HKm di ke dua lokasi melalui curah pendapat, fokus group discusion, wawancara mendalam.

2. Sosialisasi program kepada petani perserta HKm mengenai pembentukan Kelompok Usaha Bersama (KUB) yang dapat menjadi wadah peningkatan ekonomi bersama anggota

3. Musyawarah petani peserta $\mathrm{HKm}$ dalam penentuan perlunya pembentukan KUB untuk mendukung kegiatan HKm

4. Musyawarah petani peserta HKm untuk menentukan maksud dan tujuan, nama, pengurus, aturan main, kegiatan usaha dan kedudukan KUB yang dibentuk di lokasi penelitian

5. Sosialisasi keberadaan KUB dan pendaftaran anggota oleh para pengurus di kedua lokasi

Hasil identifikasi kebutuhan (needassesment) pengembangan ekonomi masyarakat tani HKm di lokasi penelitian, teridentifikasi beberapa permasalahan:

1. Masyarakat kelompok tani $\mathrm{HKm}$ memiliki motivasi yang tinggi untuk tetap mengelola HKm dengan berpedoman pada IUPHKm yang mereka terima.

2. Masyarakat kelompok tani HKm sulit mengembangkan perekonomian karena tanaman MPTs HKm yang diharapkan tidak menghasilkan.

3. Masyarakat kelompok tani HKm mengaku bahwa ada tanaman pokok HKm yang sengaja diganti dengan tanaman MPTs lainnya karena tidak produktif.

4. Saat ini di beberapa lokasi tanaman MPTs menurut pengakuan masyarakat kelompok tani HKm hanya tinggal 3\% saja.

5. Masyarakat kelompok tani $\mathrm{HKm}$ mengaku bahwa mereka lebih memilih tanaman kopi yang dianggap lebih menguntungkan.

6. Masyarakat kelompok tani HKm bersedia melakukan kegiatan konservasi lahan HKm sebagai konsekuensi dari IUPHKm.

7. Masyarakatkelompok tani $\mathrm{HKm}$ memohon agar difasilitasi dalam pengembangan usaha ekonominya terkait dengan pengelolaan $\mathrm{HKm}$

\section{c. Pembentukan Kelompok Usaha Bersama}

Kelompok merupakan suatu wadah untuk memudahkan proses dinamisasi masyarakat sasaran kegiatan agar mencapai tujuan yang ingin dicapai. Berdasarkan hasil kesepakatan dengan masyarakat kelompok tani HKm, kelompok usaha bersama (KUB) mengacu pada kelompok Gabungan Kelompok Tani (Gapoktan) yang selama ini sudah ada. Hal ini juga disepakati oleh semua anggota kelompok yang hadir pada saat pelaksanaan penelitian. Kelompok usaha bersama ini akan mengorganisir setiap kegiatan kelompok agar terkoordinasi dengan baik. berikut :

Setelah KUB terbentuk, kegiatan selanjutnya yang dilakukan adalah sebagai 
1. Musyawarah anggota KUB dalam perencanaan kegiatan usaha yang akan dilakukan jangka pendek.

2. Musyawarah anggota KUB mengenai prioritas usaha yang dilakukan, hak dan kewajiban pengurus dan anggota serta mekanisme (tata kerja) pelaksanaan kegiatan.

3. Musyawarah anggota KUB untuk menentukan kebutuhan utama (need assesment) anggota yang dapat diusahakan KUB kaitannya dengan peningkatan ekonomi dan konservasi lahan $\mathrm{HKm}$

4. Musyawarah anggota KUB mengenai permodalan awal dan sumber-sumber modal usaha KUB

5. Musyawarah anggota KUB mengenai program pengadaan tanaman MPTs melalui KUB

\section{d. Pendampingan dan Fasilitasi Pengembangan Usaha KUB}

\section{a) Pendampingan dalam Penataan Organisasi KUB}

1. Musyawarah anggota KUB dalam merumuskan rencana jangka pendek, jangka menengah, dan jangka panjang dalam pengembangan usaha bersama

2. Peningkatan kesadaran, komitmen dan loyalitas anggota kepada pengembangan usaha kelompok

3. Peningkatan kuantitas dan kualitas keanggotaan kelompok usaha bersama

4. Peningkatan penataan kelembagaan dan pengelolaan usaha (manajemen usaha kecil)

5. Peningkatan jaringan kerja sama usaha dengan berbagai pihak

6. Pengembangan aksesibilitas usaha KUB

7. Peningkatan kualitas dan kuantitas upaya konservasi lahan melalui pengusahaan komoditas tanaman MPTs yang memberikan peningkatan ekonomi

Tujuan Pendampingan dalam penataan organisasi KUB dilakukan untuk mengatur kepengurusan dan administrasi yang berorientasi pada usaha. Aspekaspek yang difasilitasi adalah :

1. Memperkokoh kepengurusan

2. Pembangkitan partisipasi anggota

3. Peningkatan pengetahuan dan pemahanan tentang kegiatan usaha

4. Pembagian tugas dan wewenang

\section{b) Pelatihan Pengembangan Usaha}

1. Pelatihan teknologi tepat guna pengolahan kopi bubuk

2. Pelatihan teknologi tepat guna sablon dan kemasan

3. Fasilitasi sistem administrasi dan pembukuan serta manajemen usaha kecil

4. Pendampingan cara pemasaran

\section{Implementasi Pelatihan Teknologi Tepat Guna Pengolahan Kopi}

Berdasarkan potensi hasil produksi kopi di lokasi penelitian, kondisi lingkungan, dan keadaan sumberdaya manusia maka dilakukan pengamatan dan diskusi antara peneliti, dengan para masyarakat petani kopi, pemuka masyarakat, dan aparat pemerintah yang bertempat di Desa Air Lanang. Hasil diskusi merumuskan rancangan pemberdayaan masyarakat petani kopi di Desa Air Lanang sebagai berikut:

1. Pembuatan model teknologi tepat guna terpadu yang sesuai dengan potensi lokal atau sesuai dengan kebutuhan/keinginan serta minat masyarakat petani kopi.

2. Pembentukan dan pengembangan kelompok sasaran masyarakat petani kopi

3. Pembuatan modul teknologi tepat guna yang mudah diadopsi oleh kelompok masyarakat petani kopi. Modul yang dibuat antara lain :
a. Modul Pengolahan Kopi Bubuk
b. Modul Usaha Sablon dan Kemasan
c. Modul Manajemen Usaha Kecil (MUK)
d. Modul Manajemen Pemasaran Kopi Bubuk 
4. Pembuatan rancangan industri kecil dengan basis kopi

5. Pemberian pelatihan teknologi tepat guna terpadu

6. Pelatihan dan pembinaan manajemen usaha : mendirikan usaha secara kelembagaan, mengelola produksi, mengelola keuangan, mengelola sumber daya manusia, dan mengelola pemasaran.

Skenario yang akan dilakukan pada penelitian tahap berikutnya adalah pelatihan dan pembagian kerja dalam kelompok untuk mempraktekkan rancangan draft modul teknologi sampai menghasilkan produk yang standar dan anggota kelompok memiliki keterampilan yang mandiri. Untuk itu perlu dilakukan evaluasi pasca pelatihan. Jika anggota kelompok masih belum bisa memproduksi secara baik dan standar dilakukan pelatihan remedial sehingga dipastikan anggota kelompok akan bisa memulai usaha secara mandiri. Semua produk yang dihasilkan pada akhir kegiatan mempunyai label nama kelompok usaha. Label bertujuan untuk memberikan karakteristik produk berdasarkan identitas kelompok dan daya saing usaha kelompok.

Kemudian, pada tahap selanjutnya tenaga peneliti membantu membuatkan rancangan awal usaha yang sesuai dengan kondisi lingkungan sehingga kelompok masyarakat petani kopi dapat memulai atau mengembangkan usahanya. Pada awal usaha masing-masing kelompok akan mengumpulkan modal usaha secara mandiri dari masingmasing anggotanya ditambah dengan bantuan modal dari program penelitian. Masingmasing kelompok usaha mempunyai tempat pemasaran produk.Pada tahap awal masingmasing kelompok mendirikan 1 warung tempat usaha di rumah salah satu anggota kelompok. Selain itu masing-masing kelompok berupaya menyalurkan dan menjual ke tokotoko, warung-warung atau rumah makan di kotakabupaten atau pusat ekonomi di kabupaten sekitarnya. Promosi dilakukan dengan membuat merek usaha dan mengusahakan tempat pamer usaha yang layak dan memadai sehingga mendukung pemasaran baik secara langsung atau tidak langsung dalam mengelola usaha.

Selain itu, peneliti juga akan membantu dalam pembinaan pengelolaan usaha berupa bantuan manajemen produksi, manajemen keuangan, pembukuan sederhana, manajemen pemasarandan praktek pemasaran produk hasil olahan. Peneliti membantu jaringan pemasaran meliputi jaringan pemasaran pasar tradisional, pasar supermarket, toko,warungwarung.

Untuk meningkatkan kepercayaan konsumen pada produk hasil olahan, peneliti membantu dalam pembinaan ke arah sertifikasi produk meliputi izin kesehatan, izin industri, label halal dan berbagai izin dalam pengembangan usaha. Peneliti dan tanaga pendamping juga mendampingi dalam pengawasan kelayakan mutu produk.

\section{Penutup}

Produktivitas tanaman kopi dapat diidentifikasi dari usia tanaman kopi dan musim tanaman kopi. Jika pada musim sela, produktivitas menurun, dan pada musim panen raya (musim agung), produktivitas tanaman tinggi, tergantung usia tanaman dan kesuburan tanah. Pemasaran produk kopi dilakukan dengan cara memasarkan dalam bentuk kopi basah dan kopi biji kering. Kopi basah memiliki nilai jual lebih rendah jika dibandingkan dengan kopi biji kering, dan kopi biji kering nilainya lebih rendah jika dibandingkan dengan harga jual produksi kopi biji hasil olahan (kopi bubuk asli).

Pada kawasan penelitian berhasil dibentuk kelompok masyarakat petani kopi yang akan berpartisipasi dalam pengembangan pengolahan kopi pasca panen untuk meningkatkan nilai tambah ekonomi produk kopi. Bersama dengan peneliti, kelompok masyarakat petani kopi merumuskan modul teknologi pengolahan kopi yang tepat berdasarkan potensi dan keinginan sumberdaya masyarakat petani kopi yang akan diujicobakan pada tahapan penelitian berikutnya.

Model pengembangan teknologi tepat diguna yang disusun disesuaikan dengan potensi sumber daya manusia yang ada, potensi sumber daya alam, keberadaan tim ahli, serta potensi lingkungan usaha yang ada. Model pengembangan diarahkan ke pembentukan kelompok masyarakat petani kopi produktif, pengembangan modul teknologi tepat guna produksi 
pengolahan kopi dan usaha sablon kemasan.Kelompok masyarakat diarahkan untuk pendirian usaha produksi pengolahan kopi dan usaha sablon kemasan melalui kegiatan pelatihan terstruktur, pendirian unit usaha, pembinaan manajemen usaha, dan pembinaan pengembangan usaha.Tim peneliti memberi bantuan konsultasi teknologi, pembinaan sertifikasi produk, serta pengembangan pemasaran. Pada kegiatan ini juga akan dikembangkan peran mitra usaha untuk mendukung pengembangan usaha, meliputi dukungan pemerintah, pengusaha, dan sumber modal.

\section{Saran}

Pemberdayaan ekonomi masyarakat petani agar lebih mendekatkan pada keberhasilan tidak dapat dilakukan secara parsial, namun perlu dilakukan secara komporensif, terpadu dan keberlanjutan. Untuk itu keterlibatan semua unsur dan komponen dibangun secara simultan. Dalam hal ini dituntut komitmen dan keterlibatan Aparat Desa atau Pemerintah Daerah untuk terlibat langsung dan terus-menerus dalam proses pendampingan dan pembinaan agar para masyarakat petani kopi termotivasi untuk bangkit dan berperan aktif dalam mambangun dan membantu peningkatan perekonomian keluarganya.

Tanaman kopi haus lahan, sehingga potensi merambah hutan lindung sangat tinggi. Program pengolahan kopi pasca panen. menjadi sangat penting karena sebenarnya secara implisit program ini bernuansa konservasi dan pelestarian hutan lindung Bukit Daun. Selain itu program ini memiliki multiplier effect, yakni meningkatkan pendapatan keluarga dan pemeranan ekonomi masyarakat petani kopi. Berdasarkan kondisi tersebut program-program bertujuan untuk mengurangi aktivitas perambahan perlu terus diupayakan, ditingkatkan dan dikembangkan, khususnya di sentra-sentra produksi kopi yang lahannya berada di hutan lindung Bukit Daun. Berdasarkan kondisi tersebut, saran yang dapat diberikan adalah

a. Program pemberdayaan masyarakat di kawasan penyangga hutan lindung perlu terus digali dan diwujudkan, agar lebih menjadi media alternatif dalam pengentasan kemiskinan berbasis konservasi dan pelestarian hutan.

b. Pola pemberdayaan ekonomi kerakyatan hendaknya dimulai dari identifikasi potensi lokal, usaha alternatif, produksi, pemasaran produk, perolehan keuntungan dan pengembangan usaha secara berkelanjutan.

c. Diperlukan pembinaan yang berkesinambungan dalam upaya pemantapan kelompok binaan dan pemantapan usaha melalui penyempurnaan proses dan hasil produksi, penyempurnaan usaha yang disesuaikan dengan kondisi lingkungan usaha baik secara internal maupun eksternal, melakukan rencana pengembangan usaha (Business Planning) yang matang serta melakukan studi banding pada usaha-usaha sejenis. Hasil dari kegiatan ini agar kelompok binaan mampu membangun jaringan kemitraan usaha dan lebih membuka cakrawala pemikiran untuk mengembangkan usaha kelompoknya secara berkelanjutan.

\section{DAFTAR PUSTAKA}

Achmad, R, 1992, Pola Belajar Kewiraswastaan Petani Miskin: Studi Kasus Di Desa MangenJawa Tengah, Jurnal Penelitian IKIP Semarang, No. 3 Tahun VIII.

Azehari, S , 1991, Analisis Situasi Wanita Di Propinsi Bengkulu.Bengkulu: Pemda Tk I dan PSW UNIB.

Badan Pusat Statistik Bengkulu, 2004, Bengkulu Dalam Angka. Bengkulu: BPS Bengkulu.

Biro Pusat Statistik, 2001, Analisis Situasi Wanita Dalam Pembangunan Di Kabupaten Bengkulu Utara. Bengkulu: Pemda Tingkat I dan PSW UNIB. 
Bogdan, Robert dan Steven J. Taylor, 1975, Introduction To Qualitative Research Method. New York: John Willey Sons.

Casson, Herbert N, 2001, Petunjuk Praktis Dalam Berusaha. Surabaya: Usaha Nasional.

Chambers, Robert dan Steven J. Taylor, 1992, Rurak Appraisal: Rapid, Relaxed and Participatory. English: Institute of Development Studies.

Chambers, Robert dan Steven J. Taylor, 1992, Rurak Appraisal: Rapid, Relaxed and Participatory. English: Institute of Development Studies.

Departemen Pendidikan Nasional, 2000, Kamus Besar Bahasa Indonesia Edisi Kedua. Jakarta: Balai Pustaka.

Departemen Sosial RI, 2008. Pedoman Penumbuhan dan Pengembangan Kelompok Usaha Bersama, www.depsos ri.go.id

Encum, 2010. Analisis Pemanfaatan Sumberdaya Lahan dengan Multipurpose Tree Species (MPTs) pada Kegiatan HKm di Hutan Lindung Bukit Daun Register 5. Tesis Pascasarjana Pengelolaan Sumberdaya Alam dan Lingkungan, FP-Pertanian UNIB, tidak dipublikasikan.

Fitiyah, 1990, Hubungan Stutus Sosial Ekonomi Petani Miskin Dengan Alokasi Curahan Kerja Wanita Pada Rumah Tangga Petani di Gunung Kidul Wonogiri,Surakarta : Lembaga Penelitian Universitas 11 Maret.

Friedrich-Ebert-Stiftung, 1996, Panduan Praktis Membina Pengusaha Kecil. Jakarta: WISOProject Promotion of Selfhelp-Activities.

Isaac, S and Michael, W. B, 1988, Handbook In Research And Evaluation. San Diego: Edits Publisher.

Kadir, M. S, 1997, “Penelitian Tindakan Untuk Pendidikan”, dalam Forum Penelitian Kependidikan: Jurnal Teori Dan Praktik Penelitian Kependidikan IKIP Malang, Tahun 9 Desember, hal. 50-68.

Kemmis, Stephen dan Robin Mc. Taggart, 1988, The Action Research Planner. Victoria: Deakin University.

Koentjaraningrat, 1981, Metode-Metode Penelitian Masyarakat (Penyunting). Jakarta: PT Gramedia.

Miles, Matthew. B, dan A. Michael Huberman, 1992, Analisis Data Kualitatif(Diterjemahkan Tjetjep Rohendi Rohidi dan Mulyarto). Jakarta: Universitas Indonesia Press.

Nasution, S, 1988, Metode Penelitian Naturalistik Kualitatif. Bandung: Tarsito.

Sekertasis Negara RI, 1999, Garis-Garis Besar Haluan Negara (GBHN). Jakarta : Balai Pustaka.

Soengkono, 2012, Inovasi Teknoligi Tepatguna Untuk Meningkatkan Produktivitas, Nilai Tambah dan Akses Pasar Usaha Mikro Di UPT Karang Cahyo Kabupaten Bengkulu, DIKTI Stranas dan Lembaga Penelitian UNIB. 
Soengkono, 2009, Model Pengelolaan Pasca Tangkap Sebagai Upaya Pengentasan Kemiskinan Mastarakat Kampung Nelayan Pulau Enggano. DIKTI Hibah Kompetitif dan Lembaga Penelitian UNIB.

Soengkono, 2007, Perilaku Adaptif Petani Kopi Pasca Pembangunan Program Hutan Kemasyarakatan Di Kabupaten Kepahiang. DIKTI Fundamental dan Lembaga Penelitian UNIB.

Soengkono, 2004, Persepsi Masyarakat Terhadap Konservasi Dan Pelestarian Taman Nasional Kerinci Seblat. Di Kabupaten Bengkulu Utara: Jurnal Penelitian Universitas Muhammadiyah Bengkulu, Edisi ke 14 No. 2 , Bulan Juni 2005, hlm.206-214.

Sudarsono, FX, 1992, Konsep Dasar Action Research(Makalah). Yogyakarta: Disajikan Dalam Penataran Tenaga Peneliti BPKS, Tanggal 23 Nopember 1992.

Suhapti, 1991, Nilai Wanita Pada Beberapa Suku Di Indonesia Ditinjau Dari Sudut Keluarga dan Tenaga Kerja. Prosiding Seminar Nasional Hasil Penelitian Perguruan Tinggi. Jakarta : Depdikbud.

Sumarno, 1994, Penelitian Tindakan (Action Research) Dalam Bidang Sosial Dan Pendidikan.Yogyakarta: IKIP.

Suminar, 1996. Stratifikasi Gender dan Status Wanita Dalam Keluarga Suku Rejang Di Propinsi Bengkulu. Lembaga Penelitian Universitas Bengkulu.

Suparlan, Parsudi, 1986, Pengantar Metode Penelitian: Suatu Pendekatan Kualitatif. Jakarta: Program Penelitian Ilmu-Ilmu Sosial Universitas Indonesia.

Tim Editorial, 1994, Participatory Rural Appraisal Gambaran Teknik-Teknik Berbuat Bersama Berperan Setara Pengkajian Dan Perencanaan Program Bersama Masyarakat. Bandung: Studio Driya Media. 